\title{
MINING-METALLURGICAL SOURCES OF POLLUTION IN EASTERN SERBIA AND ENVIRONMENTAL CONSCIOUSNESS
}

\author{
Snežana UROŠEVIĆ ${ }^{1 *}$, Milovan VUKOVIĆ ${ }^{1}$, Bojana PEJČIĆ ${ }^{2}$ and Nada ŠTRBAC ${ }^{1}$
}

${ }^{1}$ University of Belgrade, Technical Faculty in Bor, Department of Engineering Management, Vojske Jugoslavije 12, 19210 Bor, Serbia

${ }^{2}$ City of Niš Administration, Obrenovićeva 38, 18000 Niš, Serbia

*Autor for correspondence: surosevic@ttbor.bg.ac.rs

(Received May 2017; accepted June 2017)

Key words: citizens' awareness, copper production, environmental problems, RTB-mining and smelting company Bor

\begin{abstract}
The ethics of environmental protection is based on the moral responsibility of a man not to endanger his living environment because it is the only way for creating the conditions for a better life quality. Environmental consciousness (EC) is characterized by a high awareness about the environment, especially in urban areas with mining-metallurgical sources of pollution. Raising EC in such environments causes acceptance and ecological and social responsibility. A mining-metallurgical complex plant represents an important source of pollution of urban areas. In that sense, Bor is an interesting urban area having in mind that it represents one of the most important ore and metal production centers in South-East Europe. What defines the EC of Bor inhabitants is derived from the very town and its economy. The research encompasses concrete environmental problems of the mining town Bor and its surroundings. The components of the EC of people living in Bor were analyzed according to the awareness, knowledge and attitude method, having in mind the extent to which the environment has been polluted in this area. It has been concluded that the perception of people living in Bor about the state of the environment depends on numerous factors - first, whether the employee works for the RTB Bor Company or not.
\end{abstract}

Palabras clave: conciencia ciudadana, producción de cobre, problemas ambientales, minería RTB, fundidora Bor

\section{RESUMEN}

La ética de la protección ambiental se basa en la responsabilidad moral de una persona de no poner en riesgo el ambiente que habita porque es la única manera de crear condiciones para una mejor calidad de vida. La conciencia ambiental (CA) se caracteriza por el cuidado del ambiente, especialmente en zonas urbanas donde existen fuentes minero-metalúrgicas de contaminación. Promover la CA en esos medios causa aceptación y fomenta la responsabilidad ecológica y social. Una planta minero-metalúrgica representa una importante fuente de contaminación en zonas urbanas. En este sentido, Bor es un área urbana interesante, tomando en cuenta que constituye uno de los centros de producción de minerales metálicos más importantes del sudeste de Europa. Lo que 
define la CA de los habitantes de Bor se deriva de la misma ciudad y su economía. Esta investigación abarca problemas ambientales específicos de la ciudad de Bor y sus alrededores. Se analizaron las características de la CA de los habitantes de Bor de acuerdo con el modelo "conciencia, conocimiento y actitud", tomando en cuenta la magnitud de la contaminación en esta área. Se concluyó que la percepción de los habitantes de Bor respecto del estado del ambiente depende de muchos factores, siendo el más importante si la persona es o no empleada de la Compañía RTB Bor.

\section{INTRODUCTION}

The last four decades have seen a significant progress in worldwide environmental consciousness due to growing evidence of environmental threats and risks (Tsantopoulos et al. 2013). As the beginning of the 21 st century is marked by increased industrialization, the importance of air quality in urban areas in Europe has become a burning issue. According to the available reports, millions of European citizens are exposed to elevated concentrations of various air pollutants endangering their health (WHO 2013, Nikolaou 2003, Guerreiro et al. 2014). Subsequently, environmental policy has become a necessity in the urbanized world of developed and developing countries, pointing out the need of reducing health risks from air pollution (Krzyzanowski et al. 2005). For instance, the influence of traffic has numerous negative effects on the environment that can be seen on various levels (local, regional and global). Apart from the traffic-one of the biggest sources of pollution in urban areas-the scale of pollution shows that numerous industrial plants considerably pollute its surroundings. Due to the diversity in the sources of pollution as well as its potential health effects, the management of air quality seems to be one of the significant challenges for local governments throughout Europe (WHO 2013, Oltra and Sala 2015). The problem of air pollution in industrial zones is much bigger, especially in the areas with developed metallurgical facilities for production of nonferrous metals. Special attention is paid to sulphur dioxide $\left(\mathrm{SO}_{2}\right)$, a traditional air polluter.

The town of Bor (34 160 inhabitants according to the 2011 census) is a very interesting urban area, since it represents one of the most important centres of ore and metallurgy production in South-East Europe. This town is located in eastern Serbia, $220 \mathrm{~km}$ away from Belgrade and about 30 and $100 \mathrm{~km}$ away from the borders with Bulgaria and Romania, respectively. The Bor municipality covers an area of $856 \mathrm{~km}^{2}$ and is inhabited by 48615 persons, out of which 34160 live in the urban area, while the rest (nearly 15000 ) live in the 12 surrounding villages. Additionally, the town of Bor has become an administrative center of the district, which consists of four municipalities (Bor, Majdanpek, Negotin and Kladovo); it has a population of 123848 (2011 census) and covers an area of $3507 \mathrm{~km}^{2}$. This district is rich in copper and gold deposits, especially in the Bor and Majdanpek areas.

The state-owned mines of Bor are located in the eastern part of Serbia, next to the town of Bor and other six villages. Copper exploitation started in 1904 and its production was increased a few times throughout the last century. This caused the opening of new mining sites and the expansion of the factory. At this moment there are 5000 workers in nine mines operated by the mining and smelting company RTB Bor, three flotation units, two foundries, an electrolysis unit, a sulphuric acid factory, a factory of non-metal salts, and a lime factory.

When the exploitation of Bor's mines started, the ore copper content was $17 \%$ (EJATLAS 2016). First the ore was processed in France; but, as the copper content decreased, the company decided to establish a foundry in Bor in 1935. This was when the first protests against mines occurred. After an acid rain incident the people wanted somebody to pay for their ruined harvests. They did not allow anybody in or out of the factory. The turmoil ended after the military intervened with a toll of one human casualty. The former Yugoslavian government decided that farmers should not pay taxes for three subsequent years and the dispute was thus solved. Nonetheless, the government ordered the Bor Company to install a sulphuric acid filter for reducing emissions. Two new foundries were opened in the 1960s and 1970s. However, in 1989 protesters complained about the presence of radiation in Bor, which was never proven at the time (EJATLAS 2016).Currently, air and soil are polluted in Bor and its surroundings, probably due to the production processes and slag dumpsites (mostly sulphur dioxide and heavy metal particles), as well as deforestation and land erosion resulting from the opening of new mines and water pollution. Both industrial and municipal wastewaters 
have been discharged into the Borska and Kriveljska rivers without any pre-treatment. This resulted in the closing down of several wells due to pollution (Obradović et al. 2012).

The farmers won their cases against the company for polluting their crops, so they received a compensation for their loss. Detonations damaged houses in the Veliki Krivelj village, which is just $800 \mathrm{~m}$ away. Respiratory diseases and cancer occur more frequently nowadays. However, no case was brought to the court because of the lack of official health impact studies (EJATLAS 2016).

Local non-governmental organizations (NGOs) are addressing the problem through public debates, petitions, protests, and letters sent to the Serbian government. The trial against the mines is still pending. After a period of high air pollution, the foundry production closed but only for a few days.

In 2007 there was an unsuccessful attempt to privatize the mine. In 2009, after a severe pollution incident, local authorities informed the national government about the need to start a restoration project. The World Bank supported the Bor Regional Development Project, which included the construction of a new foundry and a sulphuric acid factory by the end of 2014. The restoration project was intended to expand the production and to construct the industrial and municipal waste water treatment plant which was contracted between the Bor municipality and the German company BDH Consulting Group in March 2014.

Although the new foundry was built in 2014 and started working the following year, the old foundry continued operating, so the pollution was still a problem. It was only after a series of protests that the old foundry was finally closed in November 2015.

Now RTB Bor is undergoing a complicated process of economic liquidity and restructuring. The restoration project activities were never implemented and the government had to return the resources to the World Bank and even cover penalties in May 2015. Now environmental improvements will have to be financed from the public funds, such as the new collector to conduct the Kriveljska River below the tailings in Veliki Krivelj that currently represents a ticking ecological bomb threatening the region.

\section{ENVIRONMENTAL PROBLEMS IN THE BOR AREA}

The town of Bor has developed over a relatively short period of time, a century, from a small village to a colony of miners and into an urban center of eastern Serbia (Fig. 1). The Danube provides a natural border with Romania while the Timok River flows in the vicinity of this mining area. Taking into account the fact that this town exists in the vicinity of the mine, as well as the location of the copper smelting plant and two more mines nearby (Fig. 2), which make up RTB Bor (Bor Copper Mining and Smelting Complex), the town itself (Fig. 3) represents a serious environmental problem for this region and Serbia (Dimitrijević et al. 2009).

Underground mining of copper ores in Bor began in 1903. Almost a decade later, the open pit operations started in 1912 and continued until 1986. A few decades ago two more copper mines were opened in the vicinity of Bor, at Veliki Krivelj (1979) and

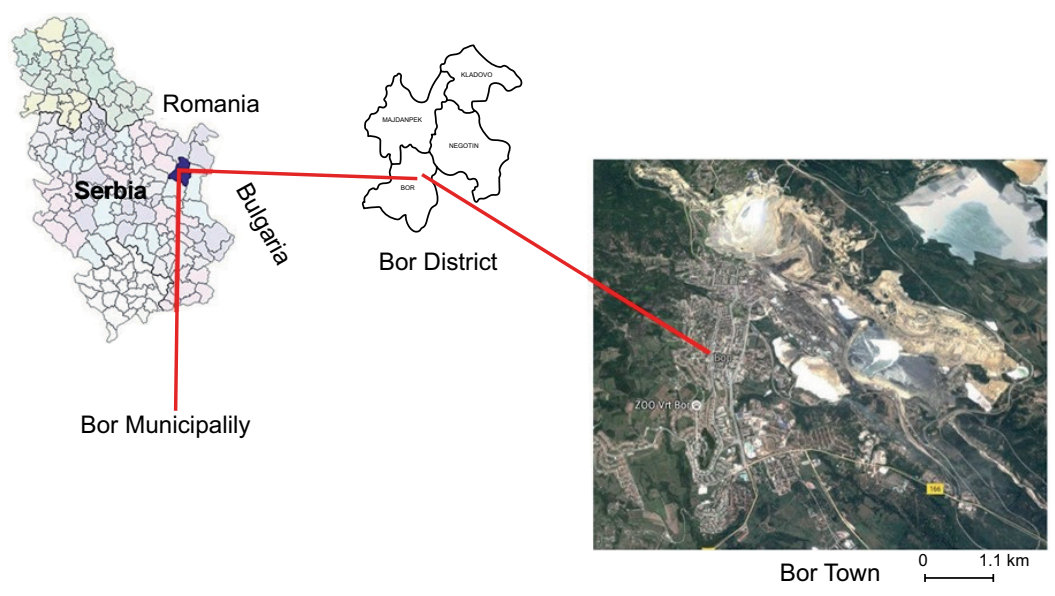

Fig. 1. Location of the Bor copper smelter ( $\left.44^{\circ} 04^{\prime} 29^{\prime \prime} \mathrm{N}, 22^{\circ} 05^{\prime} 45^{\prime \prime}\right)$ in the eastern region of Serbia (Google Maps, 30-I-2017) 


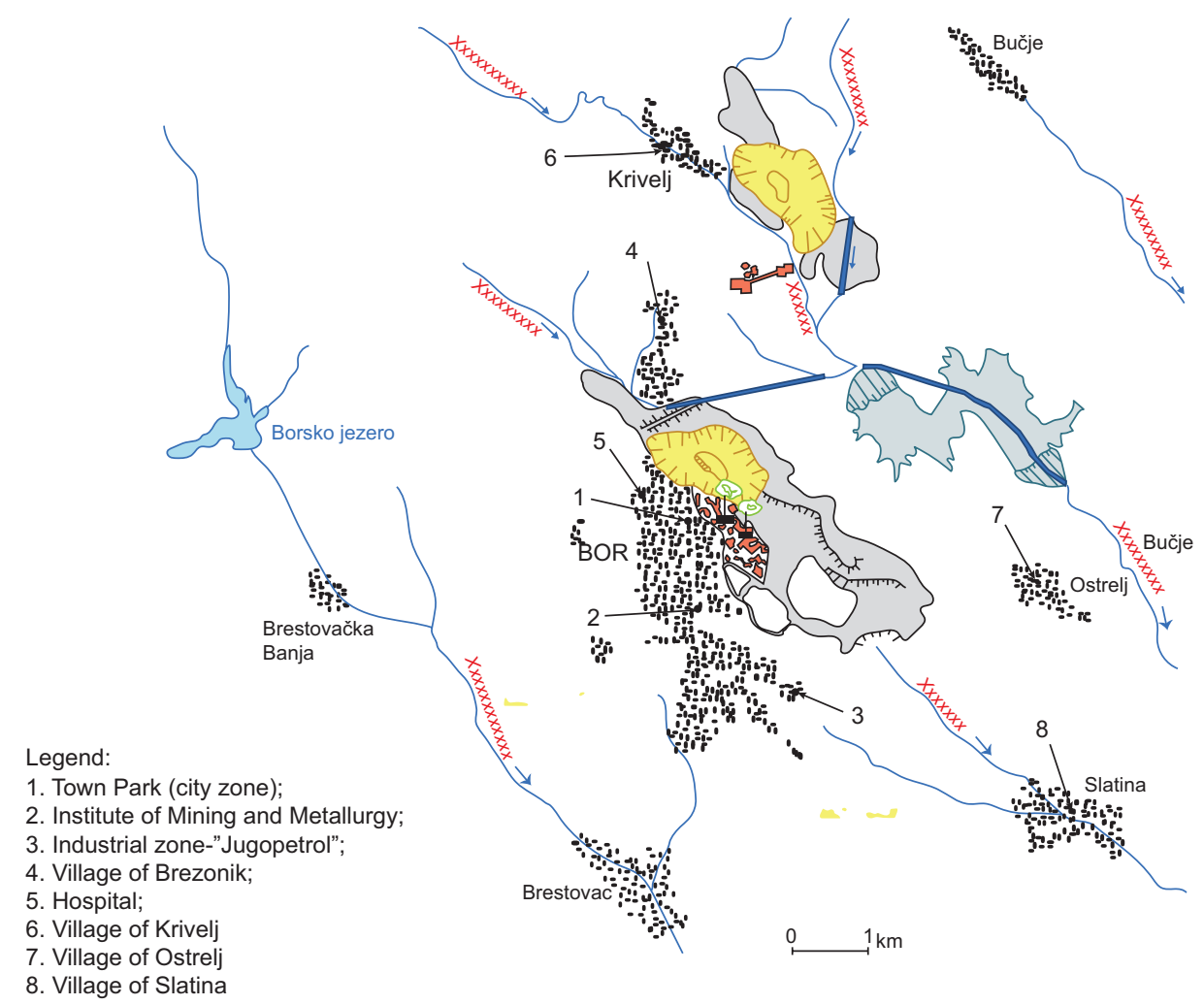

Fig. 2. Location of the study area (Nikolić et al. 2010)

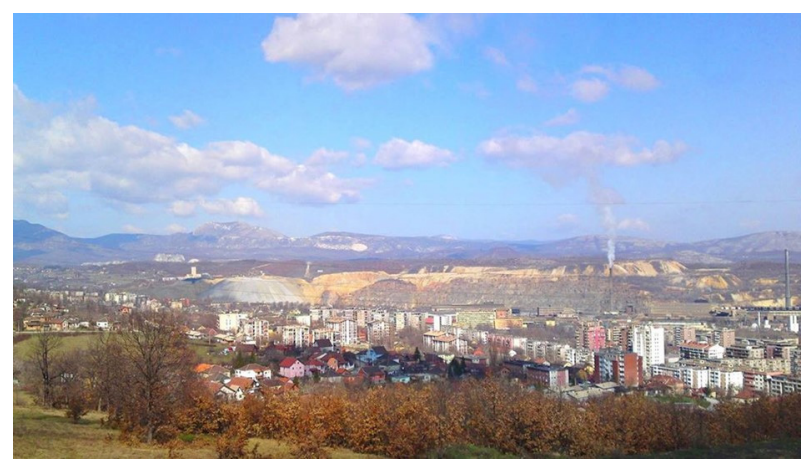

Fig. 3. The town of Bor (authors)

Cerovo (1990). These mines are situated on the north-eastern rim of the town, so that the open pit, the metallurgical smelting complex and the flotation tailings pond make a boundary between the urban and the industrial zones (Fig. 2).

The economy in Bor is extremely homogenous because $80 \%$ is composed of mining and metallurgy. Consequently, there are numerous degrading effects to the environment, which is obvious to all the citizens. At the same time, mining and metallurgy have provided the means for the development and survival of the town and a relatively high standard of living. In 2011, for instance, the average gross monthly salary in the town of Bor was 730 USD.

It is known that in Bor, a unique urban area, possibly the most important mining and metallurgical center in South East Europe, the environment and its surroundings are seriously endangered (Alagić et al. 2013, 2015, Kovačević et al. 2010, Šerbula et al. 2013a, 2014). A number of environmental impact factors in this area may be recognized, such as: (1) air pollution, (2) biodiversity loss (wildlife, agro-diversity), (3) food insecurity (crop damage), (4) loss of landscape (aesthetic degradation), (5) noise pollution, (6) soil contamination (approximately $22000 \mathrm{ha}$ ) (Dimitrijević et al. 2016), (7) soil erosion (due to acid mine drainage), (8) deforestation and loss of vegetation cover, (9) surface water pollution, (10) decreasing water quality, (11) groundwater pollution or depletion, and (12) huge waste production. Yet, mining and metallurgical activities are the most important sources of airborne metal and gaseous pollutants through both direct smelter emissions and wind erosion of mine tailing ponds.

Sulphur dioxide from smelting sulphide ores of copper is the main source of pollution in the Bor 
area. This gas originates from the pyrometallurgical process of copper recovery from sulphides such as chalcopyrite $\left(\mathrm{CuFeS}_{2}\right)$, chalcozine $\left(\mathrm{Cu}_{2} \mathrm{~S}\right)$ and covelline $(\mathrm{CuS})$. Consequently, the concentrations of sulphur dioxide released from the copper smelting process are too high. For instance, the total emission of $\mathrm{SO}_{2}$ from thr Bor Smelting Plant in 2007 was $370 \mathrm{t}$ $\mathrm{SO}_{2}$ per day, i.e. about 140000 t per year (LEAP 2003). At the same time, the distance between downtown and the first smelter chimney with $\mathrm{SO}_{2}$ emissiond is approximately $500 \mathrm{~m}$.

Data from a recent air quality analysis of the Bor mining-metallurgical complex, gathered for the period 1994-2008, indicates that daily and annual $\mathrm{SO}_{2}$ concentrations significantly exceed the current air quality standards in the studied area. A so-called hot spot, which has been the highest $\mathrm{SO}_{2}$ concentration area for 15 years, is the urban-industrial area that in fact comprises the city downtown (including the Town Park). Thus, for a period of 15 years, annual $\mathrm{SO}_{2}$ concentrations at the measuring site called Town Park have been in the range of $75-323 \mu \mathrm{g} / \mathrm{m}^{3}$ (Šerbula et al. 2013b). These values significantly exceed the annual limit values for residential areas $\left(50 \mu \mathrm{g} / \mathrm{m}^{3}\right)$ according to the Serbian regulations (The Official Gazette of the Republic of Serbia 2010). At the Town Park measuring site, $\mathrm{SO}_{2}$ concentrations exceed the permitted limits on 120 to 150 days per year on average (Nikolić et al. 2010).

Arsenic stands out among the toxic elements released by the pyrometallurgical processes of copper recovery due to its high concentrations, often greater than the regulated limiting value. The initial source of arsenic is copper ore in the form of the sulphide mineral arsenopyrite (FeAsS). The annual target value for As in the populated area, according to Serbian regulations, is $6 \mathrm{ng} / \mathrm{m}^{3}$ (The Official Gazette of the Republic of Serbia 2010). At the already mentioned measuring site of Town Park, arsenic concentrations of $18.9-323.6 \mathrm{ng} / \mathrm{m}^{3}$ have exceeded the target value in a 15-year period. This high presence of As in the urban area of Bor is a direct consequence of the vicinity of a main emission source and the unfavourable effect of wind direction (Šerbula et al. 2010).

The above mentioned $\mathrm{SO}_{2}$ and As concentrations in the Bor area, when compared to those obtained in other towns in Serbia, were several times higher (SEPA 2007). It is obvious that annual concentrations of sulphur dioxide and arsenic in the urban-industrial and suburban areas of Bor are a serious environmental problem, endangering the health of people living in this municipality. Arsenic is, for instance, classified as a human carcinogen (EC 2004).
Moreover, air pollution in Bor and its nearby rural settlements could cause an international or transboundary environmental problem, as winds reportedly carry emissions to neighbouring Bulgaria and Romania. It is obvious that the biggest long-term problem is air pollution. Thus, the first association with Bor is grey sky and the town wrapped up in smoke.

Apart from polluted air, the town and its surroundings are endangered by waste waters that pollute the soil, as well as the waste and dump sites located near the town. In the Bor area, there are several sources of water pollution, originating from the miningmetallurgical operations, such as: (1) on-going mining activities (production of sulphuric acid, copper electrolytic refining, recovery of copper sulphate and processing of slime anode); (2) drainage water from the flotation tailings which are no longer in use; (3) overburden dumps from the old, inactive mine, and (4) city-urban waste water. In any case, the current operations of the RTB Company have the biggest pollution effect on rivers in the area, especially on the Bor and Krivelj rivers (Antonijević et al. 2012, Obradović et al. 2012), which are endangered from the spring to the mouth. These rivers belong to the Timok River Basin, consequently they may have an impact on surface water along the Danube.

Over 100 years the Copper and Smelting Complex Bor (RTB Bor) produced large quantities of wastes, such as mining waste, flotation tailing and smelting slag (Stanojlović et al. 2014). In 2002, for instance, $207 \mathrm{Mt}$ of flotation tailings, $450 \mathrm{Mt}$ of overburden and $23 \mathrm{Mt}$ of slag were disposed on the territory of the Bor municipality (nearly $11333.3 \mathrm{t}$ of waste per inhabitant) (Antonijević et al. 2008). All in all, on the Bor municipality more than $1.2 \times 10^{9}$ tof mining waste are deposited: $0.9 \times 10^{9}$ t of flotation tailings and $18 \times 10^{6} \mathrm{t}$ of smelting slag (Stanojlović and Sokolović 2014).

Intensive exploitation and processing of copper with the sole aim of profiting resulted in the degradation and pollution of the environment, a process which can be described as a local ecological catastrophe. The current state of the environment is a limiting factor for development, not only of Bor but for the whole Timočka Krajina area. Therefore, it can be assumed that the environmental consciousness (EC) of Bor's citizens is influenced by the characteristics of the town itself. From the standpoint of this study, the problem of low public awareness in Bor concerning the environment should not be underestimated. It is well-known that citizens' awareness, knowledge and attitude toward different issues are the most important ways of solving problems (including environmental ones). 
Since the inhabitants of Bor have been exposed for a long time to the high concentrations of $\mathrm{SO}_{2}$ and other pollutants (especially, toxic elements in particulate matter such as $\mathrm{As}, \mathrm{Cd}, \mathrm{Cu}$ and $\mathrm{Pb}$ ), this study attempts to present the results of recently (2014) measured EC of Bor citizens. Three different groups took part in the survey conducted in this particular urban area, including the respondents employed in the mining-metallurgy production. Also, the reasons and consequences of low degrees of environmental consciousness among various groups as well as the course of their control are analyzed.

\section{ENVIRONMENTAL CONSCIOUSNESS}

Most researchers view EC as a general attitude that relates to citizens' cognitive and affective evaluation of the attitude object (environmental protection) (Dunlap et al. 2000, Hawcroft and Milfont 2010). The EC of an individual consists of (1) environmental knowledge, (2) environmental values, and (3) environmental behavior. All three components are required for knowing, adopting and practicing a pro-environmental way of life. Thus, EC consists of representations, ways of behaviors, and motives of action, willingness and expectations related to the environment.

Environmental behavior is an important foundation element of the $\mathrm{EC}$, both of an individual and of the social group. Therefore, EC is either an individual or a collective action directed towards solving identified environmental problems. Individual values may be understood as a sense-making device that shapes behavior (Husted and Allen 2008). They affect how citizens perceive and interact with each other and how they solve environmental problems (De Groot and Steg 2008, Buenrostro et al. 2014, Matei et al. 2015). EC as a manifestation of global attitudes regarding the relation between a man and nature, represents a vital element of all other social and political activities directed towards protecting the environment (Donaldson et al. 2002). Also, without the knowledge on ecological problems, any global attempt to adopt environmental values and an individual responsible behaviour towards the environment would be a failure.

\section{METHODOLOGICAL APPROACH}

In this paper we analyzed the EC of the inhabitants of Bor and its surroundings, while taking into account the level and types of environmental pollution in this area, with the aim of showing whether people are aware of the ecological situation in their area, and whether they still lack knowledge and the impulse to resolve these problems.

The research was carried out on the territory of Bor in April 2014 by using a survey questionnaire that targets the environmental awareness of citizens, their attitudes and opinions and their knowledge about relevant issues related to ecology. Since the questionnaire was conducted according to the awareness knowledge and attitude (AKA) method, which questions the level of education of respondents in relation to the environmental protection, in this survey the focus was on the correlation between the level of education of respondents and the AKA method components. The questionnaire consists of 44 questions divided into three sections.

The first section (awareness) deals with: (1) influence of the microenvironment, (2) perceptions and (3) concern about the living environment. There are five questions in relation to the influence of the microenvironment which reveal whether and how often the respondents are in touch with nature, how much the working environment inspires them to preserve the environment and what the level of their interest and involvement in these activities is. The perception represents the comprehension of the environment by the senses, which is a complex process that involves the interconnection of data acquired by the senses in prior experiences, their categorization and prioritization. Environmental perception, in fact, determines the attitudes of people in favour of or against the environment (Buenrostro et al. 2014). In this section, which has nine questions, these are related to the state of the environment (water treatment, waste disposal, air quality, etc.) where the respondents live and work. Finally, the concern about the environment is characterized by six questions that deal with the level of concern about certain problems related to the environment the respondents live and work in. The answers showed how much and whether the respondents thought about it, and if they did, their level of concern.

The second part (attitude) of the questionnaire consists of two sections which determine the environmental values. The term "environmental values" within the fields of environmental education, psychology and sociology, attempts to describe how humans view the natural environment and their relationship to it (Pauw et al. 2014). Pro-ecological attitudes put the ecosystem in the center of everything, before the economic and social development. The 
respondents were given eight questions and answers estimating to which extent they agreed or disagreed with the statements. Anthropocentric attitudes, contrary to pro-ecological, put the economic and social development in the center. These attitudes have been criticized lately. Respondents also answered the last seven questions in which they said to which extent they agreed or disagreed with the statements. The questions were successive so the respondents expressed their own attitudes.

The respondents in the third section (knowledge) answered the questions about metallurgy being the polluter of an urban area and showed their level of knowledge. Knowledge is composed of all information, facts and skills gained by a person through education or experience. The first seven questions were related to the sustainable development and metallurgy, so the respondents said whether they agreed or disagreed with the statements. The last two questions were related to the metallurgy consequences and energy consumption but they were multiple choice questions.

At the end of the questionnaire there were questions about the socio-demographic characteristics of the respondents. Due to the diversity of companies, work places and working environments, the analysis was conducted for four socio-demographic characteristics: (1) age, (2) gender, (3) level of education and (4) working experience period.

There were 360 respondents divided in three groups with the same number of members. The first group consisted of RTB Bor Group workers, the second one of those employed in educational institutions, while the third group consisted of various professions (medical workers, traders, entrepreneurs, etc.). The respondents were guaranteed anonymity and those who were involved were employed. Statistical software SPSS 18 was used in order to conduct this research.

\section{RESULTS AND DISCUSSION}

The analysis contains concrete environmental problems of the mining town of Bor and its surroundings. The structure of respondents was heterogeneous, which was one of the aims in order to consider all of the opinions and conduct a proper analysis. Within the socio-demographic characteristics of respondents there were four groups: age, gender, level of education and the length of work experience. The majority of respondents was up to 40 years of age (47\%), then 41-50 (37\%), 51-60 (14\%), and just a few of them over 60 years of age $(2 \%)$.
The highest percentage of respondents had secondary education (43\%), while the lowest number held doctoral degrees (3\%), and there were $38 \%$ with university education. According to the research results it can be concluded that the citizens know about the environmental problems, but depending on the group of respondents and their level of education, their answers differ. Two categories, age group and level of education, were found to be the key indicators of the general opinion and environmental consciousness.

\section{Descriptive statistics}

Table I presents descriptive statistics of every component of EC (ecological sensitivity, value system and knowledge) within all the groups of respondents (RTB Bor Group, educational institutions and other professions). The EC research was performed through partially standardized questions laid out as statements or attitudes.

\section{Environmental sensitivity}

In the first part, which represents environmental sensitivity, the answers were measured by the Likert's scale; the minimum number of points is 1 and the maximum is 4 . The description of Likert's scale is as follows: 1 , never; 2 , sometimes; 3 , often; 4 , very often. The four-level scale has recently been used in several empirical papers about EC (e.g., Aminrad et al. 2013, Abbas and Singh 2014).

Despite the fact that the number of alternatives usually found in Likert-type scales is five, one can say that four categories, used in this questionnaire, ensure the appropriate level of reliability and validity. Also, with four categories, it is easier for the respondents to express their opinion. Lozano et al. (2008), for instance, claimed that if too many alternatives are offered and the subjects have problems distinguishing among them, then the probability of introducing a new measurement would increase the chance of error.

The first group of questions targets the consistency of respondents and some activities related to the environmental protection. Some examples of these questions are: "Contact with co-workers makes me care about the state of the environment", "My job makes me care about the environment, and I read books and magazines dealing with ecology".

The next set of questions reveals what respondents think about the state of the environment in certain fields such as, for example, waste disposal, air quality in urban areas, soil degradation, ecological state of the environment they live in, etc. The respective meanings of the Likert's scale are: 1, much worse; 
TABLE I. ENVIRONMENTAL CONSCIOUSNESS OF THE GROUPS OF RESPONDENTS

\begin{tabular}{llccc}
\hline & Organization & Median & Std. deviation & N \\
\hline Influence of the microenvironment & RTB Bor Group & 2.20 & 0.51 & 120 \\
& Educational institutions & 2.68 & 0.67 & 120 \\
& Other occupations & 2.35 & 0.68 & 120 \\
& Total & 2.41 & 0.65 & 360 \\
\hline Perceptions & RTB Bor Group & 1.99 & 0.57 & 120 \\
& Educational institutions & 2.22 & 0.56 & 120 \\
& Other occupations & 2.07 & 0.53 & 120 \\
& Total & 2.09 & 0.56 & 360 \\
\hline Concern about the environment & RTB Bor Group & 2.54 & 0.73 & 120 \\
& Educational institutions & 2.87 & 0.64 & 120 \\
& Other occupations & 2.74 & 0.77 & 120 \\
& Total & 2.72 & 0.72 & 360 \\
\hline Knowledge & RTB Bor Group & 1.85 & 0.25 & 120 \\
& Educational institutions & 1.86 & 0.19 & 120 \\
& Other occupations & 1.92 & 0.19 & 120 \\
& Total & 1.88 & 0.21 & 360 \\
\hline Value system of pro-ecological & RTB Bor Group & 3.02 & 0.58 & 120 \\
attitude & Educational institutions & 3.09 & 0.52 & 120 \\
& Other occupations & 3.25 & 0.47 & 120 \\
& Total & 3.12 & 0.53 & 360 \\
\hline Value system of anthropocentric & RTB Bor Group & 2.67 & 0.62 & 120 \\
& Educational institutions & 2.36 & 0.54 & 120 \\
& Other occupations & 2.33 & 0.46 & 120 \\
& Total & 2.46 & 0.56 & 360 \\
\hline
\end{tabular}

RTB Bor Group: Mining and Smelting Company Bor

2, worse; 3 , better; 4, much better. On the other hand, in relation to questions dealing with the level of concern about certain ecological problems in the area they live in, the respondents expressed their opinion in one of the following ways: 1 , never worried; 2 , sometimes worried; 3 , worried; 4 , very worried.

The first five questions are related to the microenvironment and those working in educational institutions have the best results. The weakest influence of the microenvironment on the respondents is characteristic for those employed in RTB Bor Group. The other respondents indicated a higher influence of microenvironment in comparison to RTB Bor Group employees. The respondents working in educational institutions are most sensitive to microenvironmental influences (2.68).

The following nine questions deal with the perceptions of respondents. Those employed in the educational institutions have the highest perceptions in comparison to the other two groups (2.22). RTB Bor Group has the worst results once again, while the respondents working in other fields show better results.

The last six questions deal with environmental sensitivity and represent the level of concern about the environment. The situation is the same as in the previous two sections regarding the highest results. Those in educational institutions have the highest concern (2.87), and the employees of RTB Bor Group once again have the least favorable results. The respondents from other groups show better results now.

It may be said that the respondents from educational institutions showed a higher level of environmental sensitivity in comparison to the other two groups.

\section{Environmental values}

The second part of the analysis represents the values system, which consists of: (1) pro-ecological attitudes and (2) anthropocentric attitudes. Pro-ecological attitudes may hold a maximum of four points and the anthropocentric one point. The questions are interchangeable. 
The results show that those respondents belonging to the group of other professions gave the most favourable answers to the pro-ecological attitudes (3.09), and they mainly agreed with these attitudes. Those employed in educational institutions followed, while respondents of the RTB Bor Group were ranked lowest.

When talking about anthropocentric attitudes the respondents from other professions were ones again closest to the maximum number of points (2.36). The RTB Bor Group respondents were once again at the bottom of the scale. The respondents working in educational institutions had similar results to those in the group of other professions.

It can be noticed that respondents of the RTB Bor Group care more about economic development than about the environment, even though they work in the production company, which is not an excuse for such a result. Due to the fact that RTB Bor Group represents one of the biggest mining companies it should have had better plans and attitudes towards the future in order to find applicable solutions related to the environment.

Pro-ecological attitudes are related to the balance between man and nature. Moreover, human beings should adjust their activities to nature in order to maintain the balance in the environment. Some statements of this kind were considered by the respondents: "People severely endanger the environment", "Plants and animals, like people, have the right to exist", and "The balance in nature is quite fragile and can be altered quite easily". On the other hand, the anthropocentric attitudes firstly focus on social development goals (economic, social, political), and then on ecological goals. Such attitudes are becoming increasingly unpopular. Anthropocentric statements in this survey were: "Science and technology can solve any ecological problem", "People have the right to change nature in order to satisfy their needs" and "The so called ecological crisis the world is facing now, is quite over dimensioned".

The anthropocentric attitude, despite the pollution in this area, is spreading due to the growing importance of the material aspects of our existence. This is envisaged in the growing fear of losing a job in the mining and metallurgy sector. In addition, the Serbian Government is willing to privatize this company, one of the few industries left in public ownership, selling it to international companies, preferably to a Chinese partner, as it happened in April 2016, when the Chinese company (He Steel Group) became the owner of $98 \%$ of the Serbian company Železara Smederevo d.o.o. for 46 million euros.

\section{Knowledge}

The third part of the analysis consists of questions related to the knowledge of respondents. The questions are related to the mining and metallurgy and the pollution of urban areas. The first seven questions instructed respondents to choose between two answers (1, true; 2 , false), and according to these answers it could be concluded whether they knew the correct responses. The last two questions had multiple options and the respondents had to choose only one correct answer.

The group that gave the most accurate responses was the other professions group (1.92). Those employed in the educational institutions had a lower level of knowledge, and those working in the RTB Bor Group were right behind. Therefore, one might notice that RTB Bor Group employees showed the lowest level of environmental knowledge. Further on, we will discuss why that group gave the least favourable answers.

Descriptive statistics of the gathered data also disclosed that female respondents gave better answers than male respondents. These results are shown in table II.

The differences between male and female respondents are in accordance with similar studies. Gender has received a great deal of attention in the research on EC and typically this variable is seen as a key explanation of individual differences. A frequently used approach to explain these gender differences (indicated also in table II) relies on gender role and long-lasting process of socialization. Namely, the theory of socialization claims that individual development is shaped by gender expectations within the context of cultural norms. It has been known for a long time that females worldwide are socialized to be more interdependent, cooperative, compassionate, and helpful in caregiving roles; males, on the other hand, are socialized to be more independent and competitive. These differences in socialization between the genders could be attributed to the expression of more pro-environmental attitudes and behavior among women (Zelezny et al. 2000).

\section{Multiple comparisons}

In order to conduct more accurate analyses a post-hoc test of multiple comparisons has been run by using the SPSS statistical software. Table III compares AKA dimensions between the three groups of respondents (Tabachnick and Fidell 2006). According to the obtained results, minor differences between groups were noticed, which can be attributed to the poor environmental conditions. In fact, 
TABLE II. GENDER AND ENVIRONMENTAL CONSCIOUSNESS

\begin{tabular}{llcc}
\hline & Gender & $\mathrm{N}$ & Median \\
\hline Value system of pro-ecological & Males & 183 & 2.99 \\
attitude & Females & 177 & 3.26 \\
& Total & 360 & 3.12 \\
\hline Value system of & Males & 183 & 2.60 \\
anthropocentric attitude & Females & 177 & 2.32 \\
& Total & 360 & 2.46 \\
\hline Influence of the & Males & 183 & 2.32 \\
microenvironment & Females & 177 & 2.50 \\
& Total & 360 & 2.41 \\
\hline Perceptions & Males & 183 & 2.02 \\
& Females & 177 & 2.16 \\
& Total & 360 & 2.09 \\
\hline Concern about the & Males & 183 & 2.62 \\
environment & Females & 177 & 2.81 \\
& Total & 360 & 2.72 \\
\hline Knowledge & Males & 183 & 1.86 \\
& Females & 177 & 1.89 \\
& Total & 360 & 1.88 \\
\hline
\end{tabular}

the following hypothesis could be set up: the poorer the environmental conditions, the lesser the differences in the environmental consciousness. Only in the case of microenvironment there is a significance level between RTB Bor Group and the educational institutions (0.04; Table II). This confirms the aforementioned statements that educational institutions gave better answers than RTB Bor Group respondents and that the most significant difference is between both of them.

Data were also analyzed with the analysis of variance test, which confirms the assumption that the level of ecological sensitivity is lower in production organizations. The reason for this is that a big complex, such as RTB Bor Group, puts the economic interest ahead of the environment and bases its positive business results on the exploitation of natural resources. Such behavior cannot, under any circumstances, be an excuse. It should be noted that the company's greening policy depends to a large extent on the commitment and leadership of top managers, practices which are more frequently present in smaller enterprises (Boiral et al. 2014).

Therefore, efforts should be made in order to alleviate the consequences of the destroyed environment and to find environment-friendly technological solutions. Most of the respondents have secondary education and they have the best results concerning the microenvironment (2.23), due to the fact that their jobs make them aware of the constant changes in their working environment. Those with college (1.81), university (1.94) and master (1.89) degrees had good theoretical results concerning knowledge, which are shown in table III. In practice, the engagement of RTB Bor Company, during the past years, concerning the environmental protection, was lower than expected

Those included in the other professions group had solid results. They even had the best results concerning the values system. Most of the respondents in this group also have secondary education and a probable reason for their result is that they work in sectors that do not pollute the environment as much as those employed by the RTB Bor Group.

The best results were given by respondents from educational institutions because most of them have higher levels of education. The best ecological sensitivity was showed by those with a Ph.D., who showed a high level of awareness and concern for the state of the environment (the respondents had the best results regarding the micro level: 3.05 , being 4 the maximum). This is an important and promising piece of information because they are leaders in the education of future experts and educational workers who will transfer their knowledge further on.

Younger population around 40 years-old with $\mathrm{Ph} . \mathrm{D}$. and respondents with Ph.D. aged between 41 and 50 years have the highest level of knowledge, which shows their ambition for finding solutions to improve the environment and for the constant perfecting of knowledge. However, no matter how good the results are, we need to improve the education in order to achieve a higher level of EC. Consequently, we need to introduce mandatory school subjects and courses that would deal with ecology and environmental protection on all levels, starting with elementary, then secondary and tertiary education.

Pollution levels in the town of Bor are very high and they concern all the citizens, regardless of their level of education. Thus, the results are such that there are minor differences in the respondents' answers in regard to their level of education. Obviously, the deterioration of the environment in the Bor mining area, which initiated more than a century ago, has recently increased the public awareness about environmental problems. The public pressure and various stakeholders are forcing companies to reconsider their efforts regarding environmental issues (Ramanathan et al. 2014). Simultaneously, the threat of increased environmental awareness could compel mining-metallurgical companies to introduce 
TABLE III. LEVEL OF KNOWLEDGE OF RESPONDENTS IN RELATION TO THEIR LEVEL OF EDUCATION

\begin{tabular}{|c|c|c|c|c|c|}
\hline & & Descriptive statis & & & \\
\hline & Degree of education & Enterprise & Median & Std. deviation & No. \\
\hline & Completed secondary & RTB Bor Group & 1.82 & .29 & 84 \\
\hline & education & Other occupations & 1.92 & .20 & 69 \\
\hline & & Total & 1.87 & .25 & 153 \\
\hline & College degree & RTB Bor Group & 1.81 & .13 & 9 \\
\hline & & Educational institutions & 1.87 & .16 & 18 \\
\hline & & Other occupations & 2.03 & .17 & 12 \\
\hline & & Total & 1.90 & .17 & 39 \\
\hline & University degree & RTB Bor Group & 1.94 & .09 & 21 \\
\hline & & Educational institutions & 1.85 & .20 & 90 \\
\hline$\frac{000}{0}$ & & Other occupations & 1.94 & .19 & 27 \\
\hline 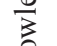 & & Total & 1.88 & .18 & 138 \\
\hline & Master's degree & RTB Bor Group & 1.89 & .16 & 6 \\
\hline & & Other occupations & 1.80 & .17 & 12 \\
\hline & & Total & 1.83 & .15 & 18 \\
\hline & Doctorate/ Phd & Educational institutions & 1.85 & .25 & 12 \\
\hline & & Other occupations & 189 & .24 & 12 \\
\hline & Total & RTB Bor Group & 1.85 & .25 & 120 \\
\hline & & Educational institutions & 1.86 & .19 & 120 \\
\hline & & Other occupations & 1.92 & .19 & 120 \\
\hline & & Total & 1.88 & .21 & 360 \\
\hline
\end{tabular}

RTB Bor Group: Mining and Smelting Company Bor

environment-friendly technologies in order to deal effectively with environmental problems. Therefore, more attention should be paid to various external societal drivers such as, for example, public awareness and consumer demand for environmentally friendly performance, as well as the influence of NGOs (Walker et al. 2008).

\section{CONCLUSIONS}

Based on the results of this study, we can conclude that the perceptions of Bor citizens about the environment depend on various factors. First of all, the EC of Bor citizens and its surroundings seems contradictory. On one hand, there is a high concern about the scope and causes of environmental problems in Bor but, on the other, there is not enough knowledge about the consequences of pollution. Respondents know facts about environmental pollution but there are not enough motivation and actions for solving these problems.

Also, there is a representation of Bor as a poor living environment and there is very little concern about its surroundings, despite the fact of being the center of biodiversity in the Balkans and Europe. $\mathrm{EC}$ is highly dependent on economy, because it is mostly approached through the economic effects of using mineral resources, and not through the sustainable use of other natural resources which may be an alternative and less harmful base of development (production of healthy food, tourism, etc.). In order to transform the current EC state of Bor citizens, the conditions should be improved for informing people about environmental issues and, as well as the involvement of citizens in solving environmental and other major problems.

Fortunately, in the last few years there have been positive changes towards reversing the inflicted damage and revitalizing and further protecting the environment. The management of the RTB Bor Company together with state officials began to improve the working conditions and to activate the key project for this town, the whole region (eastern Serbia), and the surrounding countries. Everything is still at the beginning but if it continues as planned citizens and the whole municipality can expect better living and working conditions. 
If the objectives are achieved and the efforts continue, Bor and its surrounding will be a unique example of coexistence of mining and tourism, because in the vicinity of Bor there are many interesting sites for tourists. Regarding the size of this region and population (more than 200000 ), the approach of this mining-metallurgical company's management should be based on a global orientation towards resolving pollution problems.

\section{REFERENCES}

Abbas M.Y. and Singh R. (2014). A survey of environmental awareness, attitude, and participation amongst university students: A case study. IJSR 3 (5), 1755-1760.

Alagić S.Č., Šerbula S.S., Tošić S.B., Pavlović A.N. and Petrović J.V. (2013). Bioaccumulation of arsenic and cadmium in birch and lime from the Bore region. Arch. Environ. Contam. Toxicol. 65 (4), 671-682. DOI: $10.1007 / \mathrm{s} 00244-013-9948-7$

Alagić S., Tošić S., Dimitrijević M., Antonijević M. and Nujkić M. (2015). Assessment of the quality of polluted areas based on the content of heavy metals in different organs of the grapevine (Vitis vinifera) cv Tamjanika. Environ. Sci. Polut. Res. 22 (9), 7155-7175. DOI: $10.1007 / \mathrm{s} 11356-014-3933-1$

Aminrad Z., Zakariya S.Z.B.S., Hadi A.S.H. and Sakari M. (2013). Relationship between awareness, knowledge and attitudes towards environmental education among secondary school students in Malaysia. World Appl. Sci. J. 22 (9), 1326-1333.

DOI: 10.5829/idosi.wasj.2013.22.09.275

Antonijević M., Dimitrijević D.M., Stevanović O.Z., Šerbula M.S. and Bogdanović D.G. (2008). Investigation of the possibility of copper recovery from the flotation tailings by acid leaching. J. Hazard. Mater. 158 (1), 23-34. DOI: 10.1016/j.jhazmat.2008.01.063

Antonijević M.M., Dimitrijević M.D., Milić S.M. and Nujkić M.M. (2012). Metal contamination in the soils and native plants surrounding the old flotation tailings pond of the copper mining and smelting complex Bor (Serbia). J. Environ. Monit. 14 (3), 866-877.

DOI: $10.1039 / \mathrm{C} 2 \mathrm{EM} 10803 \mathrm{H}$

Boiral O., Baron C. and Gunnlaugson O. (2014). Environmental leadership and consciousness development: A case study among Canadian SMEs. J. Bus. Ethics 123 (3), 363-383. DOI: 10.1007/s10551-013-1845-5

Buenrostro O., Márquez L. and Ojeda S. (2014). Environmental perception of solid waste management in the municipalities of Pátzcurao region, Mexico. Environm. Engn. 13 (12), 3097-3103.
De Groot J. I. and Steg L. (2008). Value orientations to explain beliefs related to environmental significant behavior. Environ. Behav. 40 (3), 330-354.

DOI: $10.1177 / 0013916506297831$

Dimitrijević M.D., Nujkić M.M., Alagić S.Č., Milić S.M. and Tošić S.B. (2016). Heavy metal contamination of topsoil and parts of peach-tree growing at different distances from a smelter complex. Int. J. Environ. Sci. Technol. 13 (2), 615-630. DOI: $10.1007 / \mathrm{c} 13762-015-0905-3$

Donaldson T. Werhane, P. and Cording M. (2002). Ethical issues in business. A philosophical approach, 7th ed. Upper Saddle River, Prentice Hall NJ, 623 pp.

Dunlap R.E., Van Liere K.D., Mertig A.G. and Jones R.E. (2000). New trends in measuring environmental attitudes: Measuring endorsement of the new environmental paradigm: A revised NEP scale. J. Soc. Issues. 56 (3), 425-442. DOI: 10.1111/0022-4537.00176

EC (2004). Council Directive 2004/107/EC relating to arsenic, cadmium, mercury and polycyclic aromatic hydrocarbons in ambient air. Official J. Eur. Commun. L 23, pp. 3-6.

EJATLAS (2016). Environmental Justice Atlas: Over a century of pollution from the Bor mines, Serbia [online]. https://ejatlas.org/conflict/over-a-century-ofthe-pollution-from-the-bor-mines-serbia 23/01/2017

Guerreiro C. B., Foltescu V. and De Leeuw F. (2014). Air quality status and trends in Europe. Atmos. Environ. 98, 376-384. DOI: 10.1016/j.atmosenv.2014.09.017

Hawcroft L.J. and Milfont T.I. (2010). The use (and abuse) of the new environmental paradigm scale over the last 30 years: A meta-analysis. J. Environ. Psychol. 30 (2), 143-158.

DOI: $10.1016 /$ j.jenvp.2009.10.003

Husted B.W. and Allen D.B. (2008). Toward a model of cross cultural business ethics: The impact of individualism and collectivism on the ethical decision-making process. J. Bus. Ethics. 82 (2), 293-305.

DOI: $10.1007 / \mathrm{c} 10551-008-9888-8$

Kovačević R., Jovašević-Stojanović M., Tasić V., Milošević N., Petrović N., Stanković S. and MatićBesarabić S. (2010). Preliminary analysis of levels of arsenic and other metalic elements in $\mathrm{PM}_{10}$ sampled near Copper smelter Bor (Serbia). Chem. Ind. Chem. Eng. 16 (3), 269-279.

DOI: $10.2298 / C I C E Q 091225049 \mathrm{~K}$

Krzyzanowski M., Vandenberg J. and Stieb D. (2005). Perspectives on air quality policy issues in Europe and North America. J. Toxicol. Environ. Health A 68 (13-14), 1057-1061.

DOI: $10.1080 / 15287390590935897$

LEAP (2003). Municipality Bor. Citizens' forum, tecnicalexpert team. .Bor, Serbia, $63 \mathrm{pp}$. 
Lozano L.M., García-Cueto E. and Muñiz J. (2008). Effect of the number of response categories on the reliability and validity of rating scales. Methodology-Eur. 4 (2), 73-79.

DOI:10.1027/1614-2241.4.2.73

Matei E., Cocoş O., Manea G. and Vijulie I. (2015). Social perception of passive pollution by asbestos in Darabani town, Botoşani country, Romania. Environ. Eng. Manag. J. 14 (5), 1137-1142.

Nikolaou K. (2003). Air quality in European urban areas and the new EC directives. J. Environ. Prot. Ecol. 4 (2), 477-482.

Nikolić Dj., Milošević N., Mihajlović I., Živković Ž., Tasić V., Kovačević R. and Petrović N. (2010). Multi-criteria analysis of air pollution with $\mathrm{SO}_{2}$ and $\mathrm{PM}_{10}$ in urban area around the copper smelter in Bor, Serbia. Water Air Soil Poll. 206 (1-4), 369-383.

DOI: $10.1007 / \mathrm{s} 11270-009-0113-\mathrm{x}$

Pauw J.B., Jacobs K. and Van Petegem P. (2014). Gender differences in environmental values: An issue of measurement. Environ. Behav. 46 (3), 373-397.

DOI: $10.1177 / 0013916512460761$

Ramanathan R., Poomkaew B. and Nath P. (2014). The impact of organizational pressures on environmental performance of firms. Bus. Ethics. 23 (2), 169-182. DOI: $10.1111 /$ beer. 12042

Šerbula S.M., Antonijević M.M., Milosević N.M., Milić S. M. and Ilić A.A. (2010). Concentrations of particular matter and arsenic in Bor (Serbia). J. Hazard. Mater. 181 (1-3), 43-51.

DOI: $10.1016 /$ j.jhazmat.2010.04.065

Šerbula S.M., Kalinović T.S., Ilić A. A., Kalinović J.V. and Šteharnik M.M. (2013a). Assessment of air bourne heavy metal pollution using Pinus spp. and Tilia spp. Aerosol Air Qual. Res. 13 (2), 563-573. DOI: 10.4209/ aaqr.2012.06.0153

Šerbula S.M., Kalinović T.S., Kalinović J.V. and Ilić A.A. (2013b). Exceedence of air quality standards resulting from pyro-metallurgical production of copper: a case study, Bor (Eastern Serbia). Environ. Earth Sci. 68 (7), 1989-1998. DOI: 10.1007/s12665-012-1886-6

Šerbula S.M., Ilić A.A., Kalinović J.V., Kalinović T.S. and Petrović N.B. (2014). Assessment of air pollution originating from copper smelter in Bor (Serbia). Environ. Earth Sci. 71 (4), 1651-1661.

DOI: $10.1007 / \mathrm{c} 12665-013-2569-7$
SEPA (2007). Environment in Serbia: An indicator - based review. Serbian Environmental Protection Agency. Belgrade, Serbia, 61 pp.

Stanojlović R.D. and Sokolović J.M. (2014). A study of the optimal model of the flotation kinetics of copper slag from Copper Mine Bor. Arch. Min. Sci. 59 (3), 821-834. DOI: 10.2478/amsc-2014-0057

Stanojlović R.D., Sokolović J.M. and Milosević N. (2014). Integrated environmental pollution from Copper Mine Bor, Serbia. Environ. Eng. Manag. J. 13 (4), 791-804.

Oltra C. and Sala R. (2015). Communicating the risks of urban air pollution to the public, a study of urban air pollution information services. Rev. Int. Contam. Ambie. 31 (4) 361-375.

Obradović Lj. Bugarin M. and Marinković V. (2012). The effect of mine facilities on pollution surrounding surface waterways. Rudarski radovi, Bor. (4), 191-196. DOI: $10.5937 /$ rudrad 12041850

The Official Gazette of the Republic of Serbia (2010). Regulation on alterations and annexes of the Regulation of conditions for monitoring and the requirements for air quality improvement. No. 75/10. ("Sl. glasnik RS”, br, 11/2010, 75/2010 i 63/2013).

Tabachnick B.G. and Fidell L.S. (2006). Using multivariate statistics. 5th ed. Allyn and Bacon, Needham Heights, MA, 980 pp.

Tsantopoulos G., Tampakis S., Andrea V. and Komitsa H. (2013). Views on environmental problems and assessment of solutions: The case of Larisa, Greece. J. Environ. Prot. 14 (2), 646-654.

Walker H., Sisto L.D. and McBain D. (2008). Drivers and barriers to environmental supply chain management practices: Lessons from the public and private sectors. J. Purch. Supply. Manag. 14 (1), 69-85. DOI: $10.1016 /$ j.pursup.2008.01.007

WHO (2013). Health effects of particulate matter. Policy implications for countries in Eastern Europe, Causasus and central Asia. World Health Organization [online]. http:/www.euro.who.int/_data/assets/pdf_file/0006/ 189051/Health-effects-of-particulate-matter-final-Eng. pdf 30/01/2017.

Zelezny L.C., Chua P.P. and Aldrich C. (2000). Elaborating on gender differences in environmentalism. J. Soc. Issues. 56 (3), 443-457. 